\title{
COLIN CAMPBELl AiKMAN: REFLECTIONS
}

\section{Rt Hon Sir Kenneth Keith}

Colin Campbell Aikman, was Professor of Law at Victoria University of Wellington from 1955 to 1968 and for much of that time he was the Dean of the Faculty. Indeed in our household for many years the expression "the Dean" meant Colin and not his successor for the time being.

I joined the faculty as a very junior member half way through Colin's time there. Although I have learned much from him in the following forty years (in the Law Commission as Alison mentioned, and in the Institute of International Affairs) I was not a student of his in the formal sense. But I have striking testimony from one who was and he begins his tribute by saying "it is very hard to lose one's chief mentor [a word that has already been used today], someone who has been a supporter (often I suspect unwittingly) throughout my adult life".

"Colin", Roger Clark continues, "was a great teacher who was wonderful in small groups and in the one-on-one interaction; at sharing from his fund of experience about the drafting of the UN Charter in San Francisco; the Universal Declaration of Human Rights; the Constitution of Western Samoa; founding the University of the South Pacific and so much else".

Today I celebrate two other aspects of Colin's stewardship in the university. The first was his role, with other senior members of a very small faculty (of just eight when I arrived), in building up its teaching strength as law teaching became full time, both for students and for staff. As in so many matters in his career - he was there at the creation. Colin had a major hand in the establishment and the development of the junior lectureship system. That system, looking back, was critical in building up law teaching and legal scholarship in New Zealand and far beyond.

Colin was able in his long and extremely busy life to see many former junior faculty members become eminent scholars in New Zealand and abroad as with Canada's two leading academic public lawyers, Peter Hogg, Dean and University Professor at Osgoode Hall Law School, and David

* Member of the Victoria University of Wellington law faculty 1962-64, and 1966-91; the New Zealand Law Commission 1986-96; and the Court of Appeal since 1996. This tribute was one of many given at a celebration of Colin Aikman's life at Old Saint Pauls, 22 January 2003. Amongst others was one which is referred to by Sir Kenneth, by Alison Quentin-Baxter, who spoke of her experience under Colin Aikman's leadership at the Legal Division of the Ministry of Foreign Affairs. 
Mullan, the Osler, Hoskin and Harcourt Professor of Constitutional and Administrative Law at Queen's University. He once said to me that one of his great joys was to see his ugly ducklings turn into swans.

The strengthening of the faculty was not only at the junior level, as one of the professorial appointments of that time, Sir Ivor Richardson, reminded me the other day.

Betty was central to all those faculty endeavours, in encouraging staff, in supporting their families, particularly as they headed off to overseas graduate study which was part of the system, in supporting students and, as Roger says, in feeding voracious harriers.

The second matter to celebrate is the expansive sense of the role of law and of the lawyer which Colin gave us. He gave it through his own example and through involving faculty colleagues in his own endeavours, for instance in drafting Pacific constitutions. That involvement went very widely beyond the faculty and beyond the university as in the Institute of International Affairs.

Lawyers, to his mind should be concerned with principles and values (as Alison has said), that is with the law as it should be, as well as with the law as it is. One example only because time is short. The redesign of the Legal System course under his direction in 1963 with that wider purpose very much in mind led directly into Colin arranging with Mr Justice Woodhouse, or perhaps it was the other way around, that a number of us should make submissions to his Royal Commission on Workers' Compensation. Those submissions, as it turned out, related very closely to the central recommendations which Sir Owen and his colleagues made.

I conclude with Roger Clark, Board of Governors Professor at Rutgers University, and with Colin as the Dean and teacher. This is what Roger says: "As my Dean, Colin was an enormously supportive superior who encouraged me to pursue my own academic enquiries even when it led me in directions that should have embarrassed him. He supported my free speech rights several times during the Vietnam War, without ever appearing to agonize about whether I was worth it. Loose cannons have their baggage, to mix a metaphor. He had a way with loose cannons. May my generation have as much influence on our students as Colin had on his!"

\section{A H Angelo*}

Dr Colin Aikman was Professor of Jurisprudence and Constitutional Law at Victoria University of Wellington from 1955 to 1966. Prior to that appointment he had been legal advisor in the Department of External Affairs. From his Victoria Chair he moved to Fiji to become Vicechancellor of the University of the South Pacific. These postings reflect the international, constitutional, and Pacific interests of Dr Aikman.

* Professor of Law, Victoria University of Wellington, Faculty of Law. 
The Law Faculty at Victoria University of Wellington was in the 1950s and 1960s a very different place from what it is today. There were then relatively few staff and few students. Further, the content of the law degree was compulsory. First contact with the Dean or one of the few other members of staff came, in those days, at enrolment time. There were invariably queues of 10 to 15 people, outside the doors of relevant staff members, waiting to have their courses for the year approved. ${ }^{1}$ The Dean, along with his colleagues, took his share of the enrolling students. Beyond this, the writer of these reflections had no significant contact with Professor Aikman, as Dean or as teacher, during his studies in the Faculty. Professor Aikman did, however, give some lectures in the constitutional and administrative law course in 1964, which left an indelible impression for two reasons. The first, and inconsequential, reason is that he came to class smoking a cigar ${ }^{2}$ and it was all very dashing.

The second, and significant, reason is that when Professor Aikman appeared to take those few classes in the constitutional and administrative law course in 1964 he was just back from the Cook Islands. He spoke of the constitutional work he was then doing there and specifically of the House of Arikis. This, in the context of Dicey and Jennings, was exotic and intriguing stuff. The lecture notes for those interesting days were filed with notes of 17 March 1964, but were themselves undated and more likely came from later in that year.

A number of interesting things emerge from the notes. Interesting because they are still of relevance today, if not in the context of the Cook Islands or Niue, at least in the context of Tokelau and Pitcairn. The first point recorded in the notes is "Are you ready for self-government? False question. Never know till you try". In the early Report to the Minister of Island Territories on the Constitutional Development of Niue by Professor Aikman and Mr J M McEwen, it is noted: ${ }^{3}$

We formed the view that the emphasis on a programme setting out stages of constitutional development that would lead within a relatively short period to full internal self-government had caused the Niuean people and their representatives a great deal of concern. We were therefore careful to point out that Niue had already received substantial instalments of self-government.

In class Professor Aikman also spoke (1) of the absence of a developed party system presenting problems both in Western Samoa (on whose Constitution he earlier worked) and in the Cook Islands, and (2) about who was to be the Head of Government (which raised the question of the role of the local chiefs). The limited franchise in Western Samoa was contrasted with the pattern of

1 It is difficult to understand why there should have been queues given the open access to courses and the absence of options, but from memory the main concern was with the workload and ordering of subjects.

2 Some colleagues suggested it was a cigarillo rather than a cigar. Was it a Partagas, Ramon Allones, or Romeo y Julieta?

3 Colin C Aikman and Jock M McEwen A Report to the Minister of Island Territories on the Constitutional Development of Niue (Wellington, 1965) para 5. 
universal suffrage in the Cook Islands. Professor Aikman explained that "the Legislative Assembly now wants local chiefs in the constitutional hierarchy" and spoke of the "method of giving tribal heads representation".

The role of the Arikis was not a feature of Professor Aikman's report of 1 October 1956 to the Ministry of Island Territories on a constitutional survey of the Cook Islands. ${ }^{4}$ It was, however, a significant issue in the later Report to the Members of the Legislative Assembly of the Cook Islands on Constitutional Development, ${ }^{5}$ presented by Professor Aikman, Professor Davidson, and Mr J B Wright in September 1963. That report, which is reproduced in the Centennial Issue of the Victoria University of Wellington Law Review, contains a special part on the "Position of Traditional Leaders", ${ }^{6}$ which concluded: ${ }^{7}$

We feel that the Arikis still have an important part to play at the Island Council level, and you may consider that, if they wish to extend their political activities beyond that level, they should seek direct election to the Legislative Assembly.

Professor Davidson did not accept that approach and at the end of the report added a personal comment about traditional leaders. He concluded: ${ }^{8}$

I fully support my colleagues in their statement that little support was shown for any of the proposals put forward. On the other hand, I believe that the discussion of these proposals can do no good and may, indeed, tend to injure the harmony of political life in the Cook Islands.

The first version of the Cook Islands Constitution, enacted on 17 November 1964 in the Cook Islands Constitution Act $1964,{ }^{9}$ made no provision for the House of Arikis. But before the Constitution came into force, ${ }^{10}$ significant changes to the Constitution were made by the Cook Islands Constitution Amendment Act 1965. ${ }^{11}$ Among other things, new articles provided specifically for the House of Arikis of the Cook Islands. The functions of the House included considering "such matters relative to the welfare of the people of the Cook Islands as may be

4 Colin C Aikman First Report on Constitutional Survey of the Cook Islands (Wellington, 1956).

5 Colin C Aikman, James W Davidson, and John B Wright "Report to the Members of the Legislative Assembly of the Cook Islands on Constitutional Development" (1999) 30 VUWLR 519.

6 Aikman, Davidson, and Wright, above, paras 53-57.

7 Aikman, Davidson, and Wright, above, para 57.

8 Aikman, Davidson, and Wright, above, "Position of Traditional Leaders" para 1.

9 Cook Islands Constitution Act 1964 (NZ), sch.

10 On 4 August 1965 - see the Cook Islands Constitution Act Commencement Order 1965 (SR 1965/128), cl 2 .

11 See the Cook Islands Constitution Amendment Act 1965 (NZ), sch 1. 
submitted to it by the Legislative Assembly for its consideration", and "express[ing] its opinion and mak[ing] recommendations thereon to the Legislative Assembly". That provision remains in the Constitution of the Cook Islands today. ${ }^{12}$ The focus in the constitutional law classes at Victoria in the autumn of 1964, was clearly a reflection of the need to respond to the constitutional aspirations of the people of the Cook Islands in this respect.

Professor Aikman told the class too of New Zealand economic support for the Cook Islands. ${ }^{13}$ The question was "How can we be sure the money will be wisely spent?". He also stated that dependence on economic support was a feature of many independent countries and drew comparisons with the quinquennial grants made by the Government to New Zealand universities.

This question of economic support has, of course, remained a matter of ongoing concern. In the report of September 1963 to the Cook Islands Legislative Assembly, Professors Aikman and Davidson and Mr Wright stated that: ${ }^{14}$

The Government of New Zealand, like yourselves, recognises that substantial financial assistance will continue to be necessary to the Cook Islands for a long time to come; and it has been made clear that this assistance will be provided in the future, as at present. Under the present arrangements, responsibility for the provision of a substantial part of your revenue rests with New Zealand and control of its expenditure rests with the Government of the Cook Islands.

The matter arose again shortly after in the context of the 1965 Report to the Minister of Island Territories on the Constitutional Development of Niue. It was reported there that: ${ }^{15}$

The particular matters that were of concern to the Niuean people were their fear that the grant of internal self-government involved an attempt by New Zealand to obtain release from her responsibilities towards Niue .... Mr. McEwen drew attention to your own view that it was for the Niueans themselves to determine the pace at which they would move towards internal self-government. He also emphasized on a number of occasions that the New Zealand Government would continue to give financial and other assistance to a self-governing Niue and its people as it had done in the past ....

That undertaking was ultimately reflected in the Constitution of Niue. ${ }^{16}$

12 Constitution of the Cook Islands, art 9.

13 At that time said to amount to about half of the Cook Islands budget.

14 Colin C Aikman, James W Davidson, and John B Wright "Report to the Members of the Legislative Assembly of the Cook Islands on Constitutional Development" (1999) 30 VUWLR 519, para 77.

15 Colin C Aikman and Jock M McEwen A Report to the Minister of Island Territories on the Constitutional Development of Niue (Wellington, 1965) para 7.

16 Niue Constitution Act 1974 (NZ), s 7. 
Not mentioned in the class of 1964, but appearing in both the First Report on Constitutional Survey of the Cook Islands of 1956 and the report on Niue of 1965, were discussions of the possible decolonisation choices. In the Cook Islands document, for instance, there is discussion of both integration and free association as options for the Cook Islands. ${ }^{17}$ The report rejected the integration option. ${ }^{18}$

The report of 1965 on Niue stated that Niue had been offered "four alternative courses of constitutional development: complete independence, integration with New Zealand, a Polynesian federation, and internal self-government". ${ }^{19}$ The report explained that: ${ }^{20}$

The Niue Island Assembly decided that internal self-government was the alternative they preferred; but,

when they were presented with a paper which set out a programme by which internal self-government

could be realised, there were reservations on their part as to the pace at which developments should take

place.

A student of constitutional law at Victoria University would be most familiar with Dr Aikman's contributions to New Zealand: The Development of its Laws and Constitution, ${ }^{21}$ the seminal work produced by Stevens and Son as part of a Commonwealth series. The New Zealand text went through two editions and remains a valuable reference point for an introduction to the legal system of New Zealand and its historical development.

After leaving Victoria University, Dr Aikman maintained strong links with the Law School and was, until his death, regularly seen in the corridors of the Law School and at Faculty gatherings and public lectures. He was also a regular contributor to debates at Law School functions and, by publication, to the Victoria University of Wellington Law Review. In 1987 Dr Aikman contributed to the memorial issue for Professor Quentin-Baxter with a paper entitled "Island Nations of the South Pacific and Jurisdiction over Highly Migratory Species",22 and to the special issue in honour

17 Colin C Aikman First Report on Constitutional Survey of the Cook Islands (Wellington, 1956) paras 3-10.

18 Aikman, above, para 5.

19 Colin C Aikman and James M McEwen A Report to the Minister of Island Territories on the Constitutional Development of Niue (Wellington, 1965) para 2.

20 Aikman and McEwen, above, para 2. The Assembly had as a consequence sought expert assistance. The 1965 report was the New Zealand Government's response to that request.

21 John L Robson (ed) New Zealand: The Development of its Laws and Constitution (2 ed, Stevens, London, 1967).

22 Colin C Aikman "Island Nations of the South Pacific and Jurisdiction over Highly Migratory Species" (1987) 17 VUWLR 101. 
of Sir Guy Powles with "Fundamental Rights and Directive Principles of State Policy in India". ${ }^{23}$ There were also his personal contributions to the 50th anniversary of the Universal Declaration of Human Rights. For this event, a seminar was held in the Law School and the contributions later published in (1999) 29 VUWLR. Dr Aikman's participation at that gathering was vintage CCA. In the questions that followed his presentation, ${ }^{24}$ he was quick, clear, and (to borrow a French epithet) ponctuel.

Others have spoken of other aspects of the life and work of Dr Aikman. The present note is in the nature of a reminiscence, focusing on aspects of a seminal lecture of the 1960s on law in the South Pacific, and on the impact of the constitutional thinking of Dr Aikman in the Pacific on a generation of students and colleagues in the Law Faculty of Victoria University of Wellington.

23 Colin C Aikman "Fundamental Rights and Directive Principles of State Policy in India" (1987) 17 VUWLR 373. There had been an earlier piece on India in (1978) 9 VUWLR 357: "The Debate on the Amendment of the Indian Constitution".

24 Colin C Aikman "New Zealand and the Origins of the Universal Declaration" (1999) 29 VUWLR 1. 
